scientists responded to the bills with alarm.

Varmus said that Clinton's intention was that any legislation should only be drafted after the NBAC had had the time to think through all the possible applications of cloning. Thomas Murray, a bioethicist at Case Western Reserve University in Cleveland, Ohio, and chairman of the genetics subcommittee of NBAC, pleaded with Ehlers not to take any "irreversible" action on the bills until the commission has had its designated
90 days to study the subject. Ehlers later described Varmus's response as "predictable", and said it would not change his plans.

Varmus also told last week's hearing that ethically defensible cloning of humans might occur in the future, citing its potential use in infertility. Such cloning "if ever to be used would be used incredibly sparingly", he said.

The bills introduced by Ehlers and Bond "will certainly stifle the research on human cells in culture that could give vast benefit to

\title{
UK embryo research law 'may need changes'
}

[LONDON] British legislation may have to be amended to enable the government to prevent techniques recently used to clone an adult sheep from being applied to human cells without controls,

according to the head of the organization responsible for licensing research on human embryos.

But Ruth Deech, the chair of the Human Fertilisation and Embryo Authority (HFA), warned a parliamentary committee last week that rigid legislation, in particular an outright ban on human cloning, could stifle potentially beneficial research.

Instead, she said, the authority would prefer to see an extension of its existing powers, giving herself or the Secretary of State for Health the authority to judge whether a particular line of research should be permitted. "We feel that the act may only require some tweaking to deal with public concern."

According to Deech, who was addressing a hearing of the House of Commons Select Committee on Science and Technology, whether new legislation is needed depends on the precise meaning of the word 'embryo' contained in the legislation passed in 1990 that set up the HFEA.

Uncertainty has arisen over whether the term 'embryo' as used in the act is sufficiently broad to cover the techniques developed by lan Wilmut and his colleagues at the Roslin Institute in Scotland (see
Nature 385, 757; 1997). The researchers took a nucleus from a developed udder cell and inserted it into an embryo cell whose own nucleus had been removed.

Wilmut himself told the House of Commons Select Committee on Science and Technology last week that, in principle, he expected it would be possible to use a similar technique to clone humans "within two years".

It is this prospect that has forced the HFEA to consider whether it has the authority to regulate such experiments under its current terms of reference. "We are 100 per cent convinced that we are able to deal with everything except the one technology that the Roslin Institute applied," Deech told the committee.

Graham Miles, the HFEA's chief legal adviser, said that discussions are taking place between the HFEA and the Department of Health about whether the terms embryo, gametes and fertilization are sufficiently broad to allaw the authority to regulate the type of cell-fusion experiments conducted at Roslin.

If the answer is negative, said Deech, it would be necessary to ask parliament to revise the wording of the act and to broaden the definition of the word 'embryo' accordingly.

Such a move would inevitably offer the opportunity to individual members of parliament opposed to embryo research in general to seek a total ban on all activities relating to human cloning. David Alton

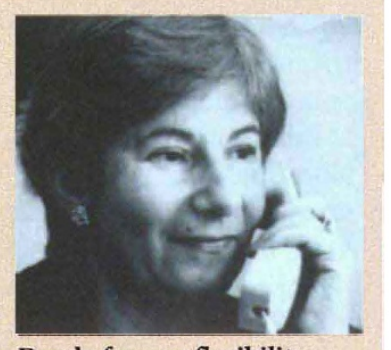

Deech: favours flexibility. (Liberal Democrat, Mossley Hill) has already called for the suspension of all cloning research in animals and humans.

Alton supports calls for an international ban. "We don't know where the DNA highway will lead, and until there has been proper discussion it is legitimate [to stop and wait]," he says.

But Deech, who claimed that Britain has "led the way in the regulation of in vitro fertilization and allied treatment", warned that a blanket ban could have serious drawbacks. "If the act does have to be amended,

we should maintain a flexible approach and leave the door open to the potential benefits of this technique," she said.

Deech's call for caution in amending the act was echoed by George Radda, secretary of the Medical Research Council. He told the select committee: "If the procedures at Roslin Institute lead to a fundamental understanding of how to turn on genes in an adult organ, that has enormous possibilities for regenerating a failed heart or a damaged brain. I want us to be able to support the best science we can that is going to advance medicine in the best way."

David Dickson people", says Roger Pedersen, a developmental geneticist at the University of California, San Francisco.

He says that Ehlers' two bills would be "disastrous" because of their use of the term 'human clone' which, technically, applies to any cell population arising from a single ancestral human cell. In principle, the bills could ban the study of how the cytoplasm of the human egg induces differentiated adult cells to return to totipotency, the state in which a cell may give rise to any kind of tissue.

They could also block studies of cellular senescence (ageing), as well as efforts to culture embryonic stem cells to provide tissues for auto-transplant.

Ehlers argues that Pedersen is trying to put his bills in "the worst possible light", and adds that he does not think that they would be interpreted as narrowly as Pedersen suggests. "I'm not trying to limit science," he said, but "most" of the experiments described "could easily be done on other mammals".

Some researchers fear that the Bond bill could also be so strictly interpreted as to stifle research. They point, for instance, to the possibly wide application of its language forbidding "research with respect to the cloning of an individual".

Experts say these ambiguities make clear that the bills will have to be substantially and precisely rewritten before they come to votes in the House and Senate. That they will ban the birth of cloned human beings seems all but certain, given the political climate. But, at stake in the revision process will be "whether we're going to permit research at the [human] embryo level with the clear prohibition that it could never be implanted in an animal or a human", says Annas.

Some argue that the Clinton ban is already redundant, as Congress banned federal funding for human embryo research in its 1996 and 1997 budgets, expanding a 1994 Clinton ban on federal funding for the creation of human embryos for research purposes to include research on spare embryos left over from in vitro fertilization.

The congressional ban, attached as a legislative rider to bills funding the Department of Health and Human Services, forbids federal funding of research in which human embryos are "destroyed, discarded or knowingly subjected to risk of injury or death". It defines embryos as being "derived by fertilization, parthenogenesis, cloning, or any other means from one or more human gametes".

Clinton said last week that this ban which he tried to reverse in his budget proposals in 1997 and 1998, on the grounds that it does not belong in legislation - does not "explicitly cover human embryos created for implantation". Nor does it cover all government agencies. 